\title{
THE INDIVIDUALITY SPHERES OF HEALTH PROFESSIONALS
}

\author{
Svetlana Nesyna \\ Immanuel Kant Baltic Federal University, Russian Federation \\ Vladislav Nesyn \\ Federal Centre of High Medical Technology (Kaliningrad), Russian Federation
}

\begin{abstract}
This study focuses on the health professionals' spheres of individuality. We surveyed three groups of health professionals - anaesthesiologists, cardiac surgeons, and cardiologists. The respondents were asked to complete an individuality questionnaire for health professionals - an update of T. Grebenuk's questionnaire for measuring teachers' individuality. The survey results show that a medical specialist's individuality is an integrated system comprising seven interconnected spheres - intellectual, motivational, volitional, emotional, practical and object-oriented, existential, and self-regulative ones, - which are affected by the development of professionally relevant components. The dominant sphere is motivational. Age and experience are associated with a lower rating given to all the components - chiefly, motivational, volitional, and self-regulative ones. No significant difference was observed between the male and the female respondents. However, the spheres of individuality differed across the three groups of health professionals. The anaesthesiologists were inclcned to give average ratings. The surgeons' and cardiologists' spheres of individuality showed significant similarities.
\end{abstract}

Keywords: individuality, spheres of individuality, professional activity, health professionals.

\section{Introduction}

Throughout human history, the individualisation of a personality has constantly increased. As a rule, individuality is used synonymously with originality, uniqueness, and personal identity. Individualisation is a process of becoming aware of one's values, originality, and integrity and of translating one's identity and the image of one's originality into behaviour, activities, and interactions with others. Individualisation also means an increased capacity to act independently and autonomously (Боброва, 1997). Although a vast body of literature focuses on individuality, the notion leaves room for research (Сайко, 2011).

A socially significant phenomenon, the work of a medical doctor is associated with strict personality requirements. The enhancement of professionalism and healthcare service quality, the achievement of professional 
and personal success and job satisfaction necessitate systematic research on the psychological aspects of medical work and on the personality and individuality of health professionals (Ясько, 2005; Карпин, 2015). This study aims to explore health professionals' spheres of individuality, using an adapted version of the health professionals' individuality map.

\section{Theoretical framework}

V. Stern was one of the first psychologists to address individuality and formulate relevant principles. Firstly, understanding the concept of individuality is possible only in terms of both unity and diversity. Secondly, when examining individuality, it is important to identify the substantial characteristics - both those with absolute value (they play the principal role and form the core of individuality) and relative value (they depend on the core elements of a personality) (Штерн, 1998). This theoretical framework determines the existing approaches to individuality studies.

Personology has offered a comprehensive and in-depth analysis of individuality. Three groups of models - research, diagnostic and psychotherapeutic ones - can be distinguished within a wide variety of theoretical constructs (Абульханова, 2009). These research models propose hypothetical parameters of a personality that are used to describe individual typological mechanisms. The models aim to identify personal abilities and limitations and the features of a personality's organisation and self-organisation. Moreover, such models reveal how a personality 'works'. G. W. Allport's and E. H. Erikson's concepts are prime examples of such research models. Diagnostic models provide evidence of certain personality traits and make it possible to describe an actual personality, using a strict set of characteristics. Such an approach was employed in H. T. Eysenck's theory of personality and in Cattell's model. Diagnostic models give a rougher approximation (Абульханова, 2009; p. 36). Psychotherapeutic models reveal the ideal of personal development and help to overcome passivity. For example, within A. Adler's model, a passive existential position can be overcome through 'creative self' - the force that allows one to use their experiences to construct a style of life. The central idea behind C. Roger's model is self-actualisation. Roger emphasised two crucial features. Firstly, a person is in constant search for experiences, which reinforce their individuality. Secondly, the self-concept - the core of individuality - is protected by defence mechanisms that prevent its destruction. This helps to preserve self-esteem, which has an immediate bearing on the significance of individuality for a personality. Another important aspect of Roger's model is the concept of a 'fully functioning person' - a person who is in touch with their feelings and works toward becoming self-actualised. 
In A. H. Maslow's model, the concepts of 'individual potential' and 'selfactualisation' comprise the foundation of individual existence. C G Jung's concept explains the logic behind the development of individuality and describes relevant mechanisms (Хьелл \& Зиглер, 2003).

Overall, there are three interconnected approaches to the phenomenon of individuality. The first approach suggests that individuality is a peculiar combination of psychological aspects of human nature. Here, the 'individual' a unique combination of features forming a sustainable unity - is counterposed to the 'typical'. Such an understanding of individuality implies that every person has individuality (Ананьев, 2001; p. 276).

The second approach introduces the idea of integrity. Originally proposed by S. L. Rubinstein, this concept was developed by V. S. Merlin. The approach focuses on the mechanism of individuality - a person's ability to summarise and synthesise their qualities, traits, etc. Individuality is determined not by a unique combination of qualities but by the effective ways to integrate them (Абульханова, 2009; р. 25-26; Орлов \& Орлова, 2011). Here, integrity is viewed both as common to all people (i.e. every human has individuality) and as constituting some kind of superior integrity (Орлов \& Орлова, 2011; p. 36). According to B. G. Ananyev, individuality is an cohesive whole and a result of integration between the individual (biological and bio-psychological elements), the personality (social and psychosocial elements), and the subject (psychobiosocial elements). Repeated differentiation and integration of these structures takes place within the actual process of the system's development and transformation into a unique polysystem that is individuality (Ананьев, 2001).

The third approach suggests that a personality becomes an individuality by achieving the highest level of development (Ананьев, 2001; Рубинштейн, 2003). This approach is a logical continuation of those considered above, as long as a balanced development of individual traits is considered. However, if the emphasis is placed on the achievement of personal perfection in line with the universal human principles (spirituality, ethics, culture), the logical connection is broken (Абульханова, 2009; p. 28). This creates a paradox.

The problem of individuality has been studied at different levels. A conceptual and methodological framework is being developed at the theoretical level. The features of the emergence, development, and implementation of individuality are being examined at the procedural level. Quantitative and qualitative measurements are being carried out at the psychometric level (Сайко, 2011; р .4).

Under the influence of hermeneutics and related psychological theories and practices (humanistic, understanding, and existential psychologies), studies are becoming less focussed on measuring psychophysiological, psychological, and sociopsychological characteristics and parameters. Greater attention is being 
paid to the internal life of a person and on how the self - which determines a person's individuality and social existence - is manifested in it. Individuality incorporates a range of psychological phenomena referred to as the 'inner space of a person'. This relatively isolated inner space is where sets of values (life plans and prospects, deep personal feelings), systems of images ('portraits', 'landscapes', 'narratives'), concepts, desires, and one’s self-esteem are formed (Ананьев, 2001; р. 274).

The study of individuality requires the registration of multiple characteristics. It is important to create a basic scheme incorporating different spheres of individuality. We believe that a promising method is O. S. Grebenyuk's concept, which covers seven spheres and emphasises the uniqueness of every person. Individuality is a fusion of intellectual, motivational, volitional, emotional, practical and object-oriented, existential, and self-regulative spheres (Гребенюк \& Гребенюк, 2000). Later, T. B. Grebenyuk proposed a concept of future teachers' individuality. As a result, a map of teachers' individuality ratings was created (Гребенюк, 2017). The Kaliningrad school of individuality studies emerged. There is a growing body of research, whose findings are being employed at local educational institutions.

The personality of a health professional has been addressed in many recent psychological studies. Within such works, two groups can be distinguished. The first group brings together explorations of personal traits - socially determined, psychological, affected by professional experiences, cognitive, and neurodynamic ones (Ясько, 2005). Some works (Донника, 2009; Грошев, 2011) address the complexes of personal characteristics and aspects. The second group comprises studies into concrete characteristics - intellectual abilities (Ражина, 2017), professional thinking (Лебедева, 2013), pursuit of success and readiness for risk (Кашапов \& Солодчук, 2017), emotional stability (Колмогорцева \& Логинова, 2009), empathic ability (Строкова et al., 2013), emotional intelligence (Васильева et al., 2013), responsibility and creativity (Кашапов \& Солодчук, 2017), internality (Романцов \& Мельникова, 2013), extroversion (Колмогорцева \& Логинова, 2009), tolerance (Шабалина, 2011), self-esteem and self-understanding (Романцов et al., 2015), self-reflection (Миронова, 2009), temperament (Строкова et al., 2013), self-organisation components (Воронин \& Николаев, 2013), professional identity (Мухортова, 2015), meaning of life (Феофанов \& Козлова, 2017), core values and meanings (Водяха, 2009), components of agency (Шабалина, 2011).

Based on O.S. Grebenyuk's concept of individuality and T. B. Grebenyuk's concept of teacher's individuality, we define a health professional's individuality as an integrated system of seven interconnected spheres - intellectual, motivational, emotional, volitional, practical and objectoriented, self-regulative, and existential ones. The individuality of a health 
professional is associated with the development of professionally relevant components of the psychological spheres, which distinguish it from the individuality of any other person.

\section{Methods}

T. B. Grebenyuk's technique (Гребенюк, 2011) for mapping teachers' individuality was adapted to the needs of this study. Changes were introduced to the content of the components. A group of experts reviewed the adapted concepts. The group consisted of 12 employees of the Federal Centre of High Medical Technology (Kaliningrad). Following the review, adjustments were made to the content of professionally relevant components of the seven spheres of individuality.

As a result, the following characteristics were identified as professionally relevant components of psychological spheres. In the intellectual sphere, these are professional thinking (ability to analyse professional situations), the ability to find best solutions and work under uncertainty and lack of information, professional knowledge, the ability to find non-standard solutions, professional intuition, etc. The motivational sphere includes the pursuit of satisfaction from the process and its outcomes, the striving for professional success and greater medical competence, the need for recognition and respect, interest in new technology, etc. The emotional sphere comprises a healthy professional selfesteem (awareness of own limits and abilities), the understanding of one's situation and resources, self-confidence (an objective assessment of one's abilities and skills), stress tolerance, etc. The volitional sphere incorporates endurance (long-term resistance to unfavourable factors), determination (readiness to achieve the desired against all odds), resolve (consistency in reaching long-term goals), etc. The sphere of self-regulation comprises the ability to organise and manage one's activities, self-mobilisation when faced with challenges, the ability to achieve objectives and to manage professional stress, etc. The existential sphere includes professional visions, orientation towards humanistic goals, professional reflection (ability to assess oneself in a professional situation), confidence, etc.

Most adjustments were made to the content of the practical and objectoriented sphere. The federal state standard for the 'Medical care' higher education programme (2016) was used as a reference.

The respondents were asked to rate themselves in regard to the professionally relevant components on a scale from one to seven. Forty-eight health professionals - employees of the Kaliningrad Federal Centre of High Medical Technology - were surveyed. The sample was divided into three groups, based on the field of expertise - anaesthesiologists $(n=16)$, surgeons 
$(\mathrm{n}=17)$ and cardiologists $(\mathrm{n}=15)$. There were 18 female $(37.5 \%)$ and 30 male (62.5\%) respondents aged 24 - 63 (a mean of 37.38 \pm 10.02 ). Professional experience ranged from 0.5 to 39 years (a mean of $13.8 \pm 9.11$ ). The survey was anonymous.

\section{Results}

1. An overview of health professionals' spheres of individuality. Each of the spheres of individuality was assigned a total rating. The highest rated were the components of the motivational sphere (the pursuit of success, selfdevelopment, professional competence, cooperation, etc), followed by the existential and practical/object-oriented spheres (awareness of life goals and values, professional confidence, professional vision). Lower ratings were given to the components of the emotional and self-regulative spheres and the lowest to those of the volitional and intellectual spheres (Table 1).

Table 1 Ratings given to health professionals' individuality spheres

\begin{tabular}{|l|l|c|}
\hline $\mathbf{N}$ & \multicolumn{1}{|c|}{ Individuality spheres } & Mean \pm Standard Deviation $(\mathbf{n}=\mathbf{4 8})$ \\
\hline 1 & Intellectual & $5.15 \pm 0.81$ \\
\hline 2 & Motivational & $\mathbf{5 . 7 8} \pm \mathbf{0 . 9 7}$ \\
\hline 3 & Emotional & $5.33 \pm 0.90$ \\
\hline 4 & Volitional & $5.18 \pm 1.04$ \\
\hline 5 & Practical and subject-oriented & $5.40 \pm 0.91$ \\
\hline 6 & Self-regulative & $5.27 \pm 1.03$ \\
\hline 7 & Existential & $\mathbf{5 . 5 0} \pm \mathbf{0 . 9 9}$ \\
\hline
\end{tabular}

A correlation analysis demonstrates a positive correlation between the ratings given to the seven spheres $(\mathrm{p} \leq 0.01)$ (Table 2).

Table 2 A correlation matrix of health professionals' individuality

\begin{tabular}{|c|c|c|c|c|c|c|c|}
\hline $\begin{array}{c}\text { Individuality } \\
\text { spheres }\end{array}$ & 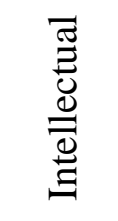 & 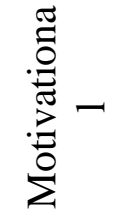 & 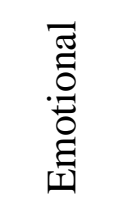 & $\begin{array}{l}\text { 즘 } \\
.0 \\
: \Xi \\
\end{array}$ & 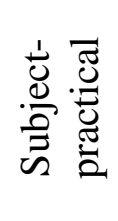 & 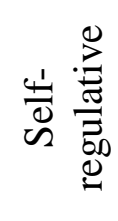 & 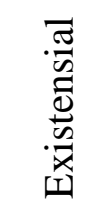 \\
\hline Intellectual & 1.000 & & & & & & \\
\hline Motivational & 0.720 & 1.000 & & & & & \\
\hline Emotional & 0.647 & 0.708 & 1.000 & & & & \\
\hline Volitional & 0.779 & 0.838 & 0.857 & 1.000 & & & \\
\hline Subject-practical & 0.750 & 0.757 & 0.732 & 0.839 & 1.000 & & \\
\hline Self-regulative & 0.770 & 0.751 & 0.939 & 0.904 & 0.781 & 1.000 & \\
\hline Existensial & 0.762 & 0.761 & 0.921 & 0.951 & 0.877 & 0.949 & 1.000 \\
\hline
\end{tabular}


2. The individuality spheres of a health professional, by age and experience. The ratings of seven individuality spheres demonstrate a negative correlation with age and professional experience. Some of the correlations are significant. These are the correlations 1 ) between age and the motivational (rs=$0.290 \mathrm{p} \leq 0.05)$ and self-regulative spheres ( $\mathrm{rs}=-0.287 \mathrm{p} \leq 0.05) ; 2)$ between professional experience and the motivational ( $\mathrm{rs}=-0.289 \mathrm{p} \leq 0.05)$ and volitional spheres ( $r s=-0.300 \mathrm{p} \leq 0.05$ ). More experienced health professionals gave a lower rating to the components of all the individuality spheres.

3. Individuality spheres, by gender. The highest ratings were given to the components of the motivational sphere, regardless of gender. The same holds true for the existential sphere. On average, male respondents gave average ratings to the components of the emotional sphere and the female respondents to those of the practical and object-oriented ones. The volitional sphere was rated the lowest. The male doctors gave lower ratings to the components of the selfregulative sphere and female doctors to those of the intellectual sphere (Table 3). Significant differences between the male and the female respondents were not revealed ( $\varphi^{*}$ Fisher, $\chi 2$ Pearson).

Table 3 Individuality spheres rated by the male and the female respondents

\begin{tabular}{|l|l|c|c|}
\hline \multirow{2}{*}{$\mathbf{N}$} & \multicolumn{2}{|c|}{ Individuality sphere } & \multicolumn{2}{c|}{ Mean \pm Standard Deviation } \\
\cline { 3 - 4 } & & male (n=30) & female (n=18) \\
\hline 1 & Intellectual & $5.27 \pm 0.85$ & $4.95 \pm 0.73$ \\
\hline 2 & Motivational & $\mathbf{5 . 7 5} \pm \mathbf{1 . 0 4}$ & $\mathbf{5 . 8 2} \pm \mathbf{0 . 8 6}$ \\
\hline 3 & Emotional & $\mathbf{5 . 4 6} \pm \mathbf{0 . 7 9}$ & $5.12 \pm 1.04$ \\
\hline 4 & Volitional & $5.24 \pm 1.06$ & $5.08 \pm 1.03$ \\
\hline 5 & Practical and subject-oriented & $5.32 \pm 0.97$ & $\mathbf{5 . 5 2} \pm \mathbf{0 . 7 9}$ \\
\hline 6 & Self-regulative & $5.18 \pm 1.06$ & $5.41 \pm 0.99$ \\
\hline 7 & Existential & $\mathbf{5 . 5 0} \pm \mathbf{1 . 0 0}$ & $\mathbf{5 . 5 0} \pm \mathbf{1 . 0 2}$ \\
\hline
\end{tabular}

4. Individuality sphere, by field of expertise (anaesthesiologists, surgeons, and cardiologists). The members of all the three groups rated highly the components of the motivational sphere. The surgeons and the cardiologists gave higher ratings to the components of the existential sphere and the anaesthesiologists to those of the emotional sphere. The volitional sphere was rated lowly across all the groups. Moreover, the anaesthesiologists gave lower ratings to the components of the intellectual sphere components, the cardiologists to those of the emotional sphere, the and surgeons to those of the sphere of self-regulation (Table 4). 
Table 4 Individuality spheres, by the field of expertise

\begin{tabular}{|l|l|c|c|c|}
\hline \multirow{2}{*}{$\mathbf{N}$} & \multicolumn{1}{|c|}{ Individuality sphere } & \multicolumn{3}{|c|}{ Mean \pm Standard Deviation } \\
\cline { 3 - 5 } & & $\begin{array}{c}\text { Anaesthesiologists } \\
(\mathbf{n = 1 6 )}\end{array}$ & $\begin{array}{c}\text { Cardiologists } \\
(\mathbf{n}=\mathbf{1 5})\end{array}$ & $\begin{array}{c}\text { Surgeons } \\
(\mathbf{n}=\mathbf{1 7})\end{array}$ \\
\hline 1 & Intellectual & $4.63 \pm 0.69$ & $5.18 \pm 0.61$ & $5.62 \pm 0.80$ \\
\hline 2 & Motivational & $\mathbf{5 . 3 3} \pm \mathbf{0 . 9 3}$ & $\mathbf{6 . 0 0} \pm \mathbf{0 . 8 9}$ & $\mathbf{6 . 0 0} \pm \mathbf{0 . 9 8}$ \\
\hline 3 & Emotional & $\mathbf{5 . 1 6} \pm \mathbf{0 . 8 2}$ & $5.16 \pm 1.00$ & $5.65 \pm 0.84$ \\
\hline 4 & Volitional & $4.75 \pm 0.90$ & $5.27 \pm 1.02$ & $5.50 \pm 1.11$ \\
\hline 5 & $\begin{array}{l}\text { Practical and subject- } \\
\text { oriented }\end{array}$ & $5.00 \pm 1.00$ & $5.55 \pm 0.83$ & $5.64 \pm 0.79$ \\
\hline 6 & Self-regulative & $4.95 \pm 1.00$ & $5.36 \pm 1.03$ & $5.47 \pm 1.05$ \\
\hline 7 & Existential & $5.09 \pm 0.96$ & $\mathbf{5 . 5 7} \pm \mathbf{1 . 0 8}$ & $\mathbf{5 . 8 3} \pm \mathbf{0 . 8 6}$ \\
\hline
\end{tabular}

There are statistically significant differences between the ratings given by the members of each group to the self-regulative spheres $(\chi 2=6.77 \mathrm{p} \leq 0.05$; $\chi 2=10.74 \mathrm{p} \leq 0.01)$. Not many anaesthesiologists rated highly the motivational (25\%) (cardiologists: $73.3 \%, \varphi^{*}=2.80$; surgeons: $64.7 \%, \varphi^{*}=2.36 \mathrm{p} \leq 0.01$ ) and the self-regulative sphere (25\%) (cardiologists: $73.3 \%, \varphi^{*}=2.80 \mathrm{p} \leq 0.01$; surgeons: $\left.52.9 \%, \varphi^{*}=1.67 \mathrm{p} \leq 0.05\right)$.

A comparative analysis of the ratings given by the anaesthesiologists and the surgeons showed the following. Among the surgeons, there were significantly more respondents giving a higher rating to the volitional sphere (surgeons: $70.6 \%$, anaesthesiologists: $31.3 \% ; \varphi^{*}=2.32 \mathrm{p} \leq 0.01$ ), the existential sphere (surgeons: $70.6 \%$, anaesthesiologists: $31.3 \% \varphi^{*}=2.32 \mathrm{p} \leq 0.01$ ), the intellectual sphere (surgeons: $64.7 \%$, anaesthesiologists: $31.3 \% \varphi^{*}=1.95$ $\mathrm{p} \leq 0.05)$ and the self-regulative sphere (25 \%) (surgeons: $52.9 \%$, anaesthesiologists: $\left.25 \% \varphi^{*}=1.67 \mathrm{p} \leq 0.05\right)$. Among the anaesthesiologists, there were significantly more respondents giving average ratings to the intellectual sphere (anaesthesiologists: $81.3 \%$, surgeons: $58.8 \% \varphi^{*}=2.12 \mathrm{p} \leq 0.05$ ), the motivational sphere (anaesthesiologists: $75.0 \%$, surgeons: $35.3 \% \varphi^{*}=2.36$ $\mathrm{p} \leq 0.01$ ), the emotional sphere (anaesthesiologists: $81.3 \%$, surgeons: $41.2 \%$ $\varphi^{*}=2.73 \mathrm{p} \leq 0.01$ ), and the volitional sphere (anaesthesiologists: $75.0 \%$, surgeons: $\left.47.1 \% \varphi^{*}=1.68 \mathrm{p} \leq 0.05\right)$.

A comparative analysis of the ratings given by the cardiologists and the anaesthesiologists demonstrates that the cardiologists were significantly more inclined to give higher ratings to the self-regulative sphere components (cardiologists $-73.3 \%$, anaesthesiologists: $25 \% \varphi^{*}=2.80 \mathrm{p} \leq 0.01$ ). Among the anaesthesiologists, there were significantly more respondents who gave average ratings to the motivational sphere components (anaesthesiologists: $75 \%$, cardiologists: $\left.33.3 \% \varphi^{*}=2.40 \mathrm{p} \leq 0.01\right)$. 
A comparative analysis of the cardiologists and the surgeons shows that, among the cardiologists, significantly more respondents gave an average rating to the components of the intellectual sphere (cardiologists: $86.7 \%$, surgeons: $\left.58.8 \% \varphi^{*}=1.65 \mathrm{p} \leq 0.05\right)$.

Overall, most differences were found between the anaesthesiologists and the other respondents. The anaesthesiologists were significantly less inclined to give higher ratings to their development in the intellectual $\left(\varphi^{*}=1.94 \mathrm{p} \leq 0.05\right.$; $\left.\varphi^{*}=3.64 \mathrm{p} \leq 0.01\right)$, motivational $\left(\varphi^{*}=2.43 ; \varphi^{*}=2.24 \mathrm{p} \leq 0.01\right)$, volitional $\left(\varphi^{*}=2.57\right.$; $\left.\varphi^{*}=3.65 \mathrm{p} \leq 0.01\right)$, and existential spheres $\left(\varphi^{*}=1.69 ; \varphi^{*}=1.77 \mathrm{p} \leq 0.05\right)$, as compared to the cardiologists and the surgeons. The differences between the surgeons and the cardiologists were insignificant.

\section{Discussion}

The data obtained from the survey show that the individuality of a health professional is a complicated combination of various subsystems. Individuality is an integrated system (Ананьев, 2001). A positive correlation between all the spheres of individuality proves this proposition. The motivational sphere is pivotal to the complicated system of individuality. This sphere was ranked the highest, regardless of gender and the field of expertise. It seems that the pursuit of satisfaction from the process and outcomes, the desire for professional success and greater competence, and the need for recognition and respect are essential to the structure of a health professional's individuality.

Older and more experienced doctors gave lower ratings to the development of the components of all spheres of individuality and, particularly, the motivational sphere. This can be interpreted as an early sign of occupational fatigue and, perhaps, professional burnout. The work of a health professional is emotionally demanding and it is associated with constant stress. Medical doctors are exposed to the double social and psychological stress - a product of dealing with the problems of both their patients and their own on an everyday basis. After hours, health professionals still experience the participation effect, with their thoughts constantly returning to the workplace (Сокол, 2015).

Studies have emphasised the need for teaching stress management to medical doctors (Юсупова et al., 2016). Of significant importance for the professional and personal development of health professionals is emotional intelligence (Васильева, 2012).

Surgeons, anaesthesiologists, and cardiologists are constantly faced with situations that require strong will and resolve (patient's death from an incurable disease; objective limits of professional abilities; unfounded criticism, etc.) (Ясько, 2005; Кобякова et al., 2016). Older medical doctors give lower ratings to the components of the volitional sphere. 
The medical profession is associated with stringent social-psychological requirements and characterised by high intellectual and emotional strain. Although there are differences between the three respondent groups identified based on the field of expertise, the members of each group have great professional responsibility and they are able to make independent decisions (Семенова et al., 2017). Surgeons and anaesthesiologists need resolve and determination to act in critical situations and under time pressure (Силкина et al., 2014). It is logical to expect that the ratings given by surgeons and anaesthesiologists will have a lot in common. However, our study revealed a greater number of similarities between the surgeons and the cardiologists. This requires a further study.

\section{Conclusions}

The individuality of a medical doctor is an integrated system of seven interconnecting spheres - intellectual, motivational, emotional, volitional, practical and object-oriented, self-regulative, and existential ones. A health professional's individuality is characterised by the development of professionally relevant components of psychological spheres, which distinguish it from the individuality of any other person.

The motivational sphere is pivotal to the individuality of a health professional. The pursuit of satisfaction from the process and outcomes, the desire for professional success and greater medical competence, the need for recognition and respect, interest in modern technology, etc. are essential to the development of a medical doctor's individuality.

Lower ratings of professionally relevant components of the motivational sphere were given by older and more experienced professionals. This can be a sign of occupational fatigue and burnout. The work of anaesthesiologists, surgeons and cardiologists is associated with situations that require a strong will and resolve to overcome difficulties. Greater experience is associated with lower ratings given to self-regulation and volitional characteristics.

The ratings given by male and female participants did not differ significantly.

The spheres of individuality differ depending on the field of expertise. The anaesthesiologists were inclined to give average ratings to the components of individuality spheres, whereas the surgeons and the cardiologists demonstrated significant similarities. This finding requires further examination. 


\section{References}

Абульханова, К. А. (2009). Проблема индивидуальности в психологии. Психология индивидуальности: Новые модели и конщепщии. Под ред. Старовойтенко Е. Б., Шадрикова В. Д. Москва: Издательство МПСИ. 14-71.

Ананьев, Б. Г. (2001). Человек как предмет познания. Санкт-Петербург: Питер.

Боброва, Е. Ю. (1997) Основы исторической психологии. Санкт-Петербург: Издательство Санкт-Петербургского Университета.

Васильева, Н. Г. (2012). Эмоциональный интеллект и синдром выгорания у медицинских работников (литературный обзор). Сибирский вестник психиатрии и наркологии. 6, 47-51.

Васильева, Н. Г., Бабурин, И. Н., \& Чехлатый, Е. И. (2013). Особенности эмоционального интеллекта врачей. Вестник психотерапии, 45, 84-98.

Водяха, А. А. (2009). Исследование ценностно-смысловых ориентаций личности как фактора сформированности профессиональной идентичности врача. Вестник Томского государственного университета, 324, 321-324.

Воронин, А. Н., \& Николаев, Е. Л. (2013). Психологические характеристики самоорганизации в профессиональной деятельности врача. Прикладные информационные аспекты медицины. 1, 13-18.

Гребенюк, О. С., \& Гребенюк, Т. Б. (2000). Основы педагогики индивидуальности. Калининград: Калининградский государственный университет.

Гребенюк, Т. Б. (2017). Формирование индивидуальности студента - будущего педагога. Lap Lambert Academic Publishing.

Гребенюк, Т. Б. (2011). Современные проблемь педагогики индивидуальности. Эмпирические исследования. Калининград: Издательство БФУ им. И.Канта.

Донника, А. Д. (2009). Профессиональный онтогенез: мотивационно-сочиологические и психолого-этические проблемы врачебной деятельности. Москва: Издательство Академии Естествознания.

Ражина, Н. Ю. (2017). Интеллект как профессионально значимое качество врача. Общество: сочиология, психология, педагогика, 8, 63-65.

Каприн, А. Д., Костин, А. А., Пономаренко, Б. Т., \& Самсонов, Ю. В. (2015). Психологические аспекты врача в процессе его профессионализации. Исследования и практика в медицине, 2, 81-84.

Кашапов, М. М., \& Солодчук, О. Н. (2017). Динамика личностных качеств врача на этапах профессионализации. Коллекция гуманитарных исследований, 4, 66-80.

Кобякова, О. С., Деев, И. А., Куликов, Е. С., Пименов, И. Д., \& Хомяков, К. В. (2016). Эмоциональное выгорание у врачей и медицинские ошибки. Есть ли связь? Социальные аспекты здоровья населения, 1, 5-18.

Колмогорцева, Н. Н., \& Логинова, С. П. (2009). Исследование проблемы характерологических особенностей личности и эффективности деятельности у врачей. Психология и педагогика: методика и проблемы практического применения, 1-6, 88-91.

Лебедева, Л. А. (2013). Психолого-акмеологические аспекты развития профессионального мышления врача-терапевта. Актуальные проблемы $u$ перспективы развития современной психологии, 1, 250-257. 
Миронова, Т. Л. (2009). Структура актуального Я-образа у врача-хирурга как субъекта профессиональной деятельности. Вестник Бурятского государственного университета, 5, 153-165.

Мухортова, В. Н. (2015). Профессиональная идентичность российских врачей: результаты социологических исследований. Социология и право, 4, 63-77.

Орлов, А. Б., \& Орлова, Н. А. (2011). Индивидуальность vs. Индивидность: роковой вопрос современности. Мир психологии, 1, 32-44.

Романцов, М. Г., \& Мельникова, И. Ю. (2013). Локус контроля личности врачапедиатра. Международный журнал экспериментального образования, 10, 317-321.

Романцев, М. Г., Храмцова, Е. Г., \& Мельникова, И. Ю. (2015). Личностномотивационная направленность врачей-педиатров. Евразийский Союз Ученых, 6, 128-131.

Рубинштейн, С. Л. (2003). Бытие и сознание. Человек и мир. Санкт-Петербург: Питер.

Сайко, Э. В. (2011). Индивидуальность каждого в уникальном ее выполнении как универсального феномена социального. Мир психологии, 1, 3-14.

Семенова, Н. В., Вяльцин, А. С., Авдеев, Д. Б., Кузюкова, А. В., \& Мартынова, Т. С. (2017). Эмоциональное выгорание у медицинских работников. Современные проблемы науки и образования, 2, 37-47.

Силкина, А. А., Саншокова, М. К., \& Сергеева, Е. С. (2014). Синдром «эмоционального выгорания» среди врачей различных специальностей в России и за рубежом. Бюллетень медииинских Интернет-конференций, 11, 1247-1250.

Сокол, А. Ф. (2015). Здоровье и болезни врачей: динамика социально-психологических особенностей. Здоровье и образование в ХХІ веке, 4, 83-87.

Строкова, Е. В., Наумова, Е. А., Шварц, Ю. Г., \& Семенова, О. Н. (2013). Влияние личностных особенностей лечащего врача на приверженность пациентов к длительному лечению сердечно-сосудистых заболеваний. Саратовский научномедииинский журнал, 2, 263-269.

Феофонов, В. Н., \& Козлова, Ю. В. (2017). Взаимосвязь профессионального выгорания и уровня осмысленности жизни у врачей. Ученые записки Российского государственного сочиального университета, 1, 62-71.

Хьелл, Л., \& Зиглер, Д. (2003). Теории личности. Санкт-Петербург: Питер.

Шабалина, Е. В. (2011). Выявление взаимосвязи субъектных и толерантных качеств врачей. Международный журнал экспериментального образования, 8, 79-80.

Штерн, В. (1998). Дифференциальная психология и ее методические основы. Москва: Наука.

Юсупова, Е. Ю., Нямцу, А. М., \& Сторожок, М. А. (2016). Распространенность и структура синдрома эмоционального выгорания у медицинских работников. Университетская медицина Урала. 3, 49-52

Ясько, Б. А. (2005). Психология личности и труда врача. Ростов-на-Дону: Феникс. 